\title{
Thematic Issue: Environment and Health in China-I
}

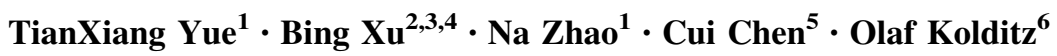

Received: 1 September 2015/Accepted: 8 September 2015/Published online: 21 September 2015

(C) Springer-Verlag Berlin Heidelberg 2015

\section{Introduction}

Combining and solving environment and health is a major issue in China-a country with tremendous economic development perspectives. Recent developments (e.g., the Tianjin Harbor accident in August 2015) show that China is investing more and more resources and efforts to cope with the industrial development (GDP) into alliancing with environmental safeguarding. The Thematic Issue on Environment and Health in China is a starting point for discussion of a variety of environmental issues, such as distribution and fractionation of rare earth elements in soil-water system and human blood (Li et al. 2014a, b, c, d); spatial evaluation of phosphorus retention in riparian zones using remote sensing data concerning the big and scarce data issues (Dong et al. 2014); toxicity contamination and distribution in soils and plants (Li et al. 2014a, b, c, d); the status and challenges of water pollution problems in China: learning from the

\section{Cui Chen}

cui.chen@ufz.de

TianXiang Yue

yue@1reis.ac.cn

Bing Xu

bingxu@tsinghua.edu.cn

Na Zhao

zhaon@1reis.ac.cn

Olaf Kolditz

olaf.kolditz@ufz.de

1 Institute of Geographical Sciences and Natural Resources Research (IGSNRR), University of Chinese Academy of Sciences (UCAS), 11A, Datun Road, Anwai, Beijing 100101, China

2 Department of Geography, University of Utah, 260 S. Central Campus Dr., Rm. 270, Salt Lake City, UT 84112-9155, USA
European experience (Zhou et al. 2014); the Heihe River basin (Xiao et al. 2014), identifying interactions between river water and groundwater in the North China Plain using multiple tracers (Dun et al. 2014); potential hazardous elements (PHEs) in atmospheric particulate matter (APM) in the south of Xi' an during the dust episodes of (2001-2012) chemical fractionation; ecological and health risk assessment ( $\mathrm{Li}$ et al. 2014a, b, c, d), occurrence and hydrogeochemistry of fluoride in alluvial aquifer of Weihe River ( $\mathrm{Li}$ et al. 2014a, b, c, d); contamination assessment and health risk of heavy metals in dust from Changqing industrial park of Baoji (Wang et al. 2014a, b); contamination assessment and health risk of heavy metals in dust from Changqing industrial park of Baoji (Su et al. 2014); sources and transports of polycyclic aromatic hydrocarbons in the Nanshan Underground River, China (Alam et al. 2014); introducing a land-use-based spatial analysis method for human health risk evaluation of soil heavy metals (Wang et al. 2013a, b, c);

3 Department of Geography, Tsinghua University, Beijing 100084, China

4 Department of Geography, Beijing Normal University, Beijing 100084, China

5 Department of Environmental Informatics (ENVINF), Helmholtz Centre for Environmental Research (UFZ), Sino-German Research Centre for Environmental Information Science (RCEIS), Permoserstraße 15, 04318 Leipzig, Germany

6 Department of Environmental Informatics (ENVINF), Helmholtz Centre for Environmental Research (UFZ), Applied Environmental Systems Analysis (TU Dresden), Sino-German Research Centre for Environmental Information Science (RCEIS), Permoserstraße 15, 04318 Leipzig, Germany 
environmental quality assessment and spatial pattern of potentially toxic elements in soils of Guangdong Province (Yang et al. 2013); fraction of $\mathrm{Cd}$ in oasis soil and its bioavailability to commonly grown crops in Northwest China (Wang et al. 2013a, b, c); microscopic morphology and elemental composition of size-distributed atmospheric particulate matter in Urumqi (Yin et al. 2013); arsenic movement and traces in the groundwater from the Hetao area, Inner Mongolia (Zhang 2013); multivariate statistical approach to identify heavy metal sources in agricultural soil around an abandoned $\mathrm{Pb}-\mathrm{Zn}$ mine in Guangxi Zhuang (Huang et al. 2013); hydrogeochemical characteristics of central Jianghan (Zhou et al. 2013); contamination and transfer of potentially toxic elements and their relations with iron, vanadium and titanium in the soil-rice system from Suzhou region (Wang et al. 2013a, b, c).

Environment and health in China has an international perspective as well as can be seen (Al-Khashman 2013) about introducing a land-use-based spatial analysis method for human health risk evaluation of soil heavy metals, natural and artificial radioactivity distribution in soil, rock and water of in gold mines (Faanu et al. 2013), exceedance of air quality standards resulting from pyro-metallurgical production of copper (Serbula et al. 2013), exceedance of air quality standards resulting from pyro-metallurgical production of copper (Tay and Biney 2013). Several thematic issues in EES are dedicated to this topic, in particular dealing with safe water supply in growing urban catchments in China related to mega-cities such as Beijing, Chaohu, Hefei, Kunming (Wang et al. 2015a, b, c, d), Shenyang, Harbin (Song et al. 2015) and greater Shanghai (Xi et al. 2015).

Learning from Integrated Water Resources Management (IWRM) research in Europe became a valuable resource of knowledge for China. This includes modeling (Beinhorn et al. 2005; Beyer et al. 2006; Centler et al. 2010; Kalbacher et al. 2012) and benchmarking (Maxwell et al. 2014; Steefel et al. 2015) as well as monitoring concepts (Rink et al. 2012) as well as comprehensive IWRM strategies for different regions of the world (Kalbus et al. 2012; Grathwohl et al. 2013; Seegert et al. 2014; Chen et al. 2015a, b).

\section{Environment and health in China-I}

This thematic issue consists of four aspects:

1. Methods for high-accuracy surface modeling (HASM) to reduce uncertainty of spatial simulation,

2. Approaches to speeding up simulation processes to find solutions for big-data problems,

3. Analyses of environmental components for health models,

4. Modeling highly pathogenic avian influenza.
A surface of an environmental component can be simulated with HASM when their spatial resolution is fine enough, which is uniquely defined by both satellite observations and ground observations. HASM can be used for spatial interpolation, data fusion and data assimilation according to availability of data sources and models (Yue et al. 2015). Spatial interpolation provides effective means to construct a continuous surface from discrete data, for which uncertainty can be considerably improved by introducing global information extracted from the discrete data using geostatistics. Data fusion is to improve the quality of the information so that it is more accurate than would be possible if the data sources were used individually ( $\mathrm{Xu}$ and Gong 2008; Mitchell 2012). Data assimilation is to use measured observations in combination with a system model in order to derive accurate estimates of the current and future states of the system (Nichols 2010). Two parallel algorithms are developed for conducting calculation with big-data, of which one is based on multi-grid method accelerated by graphic processor unit (Yan et al. 2015) and another one is based on master-slave mode (Zhao et al. 2015b). The environmental components include elevation (Yang et al. 2015a, b; Zhao et al. 2015a), land cover (Fan et al. 2015), precipitation (Wang et al. 2015a; Guo et al. 2015), environmental risks of dust storms (Xie et al. 2015a, b), water (Chen et al. 2015a, b), water chemistry (Qu et al. 2015), and physical properties of soils (Cao et al. 2015; Li et al. 2014a, b, c, d; Guo et al. 2015), riverine invertebrate communities (Jähnig et al. 2015), forecasting of precipitation (Zhao et al. 2015b, c) and trees (Wang et al. 2015b) as well as environmental technology development (Xie et al. 2015a, b). The issue also contains a comparison of environmental legislation approaches in China and USA concerning the sustainable development of coal industry (Dzonzi-Undi and Li 2015). Finally, risk of highly pathogenic avian influenza is analyzed on the basis of parameterizing health models by using research results of the environmental components, which will be mainly involved in the forthcoming Thematic Issue "Environment and Health in China-II" (Huang et al. 2016).

\section{Poyang Lake}

A special area of research interest is the Poyang Lake area (Fig. 1). This area has a tremendous importance for Chinese aquatic ecosystems research concerning various aspects, the nutrient distribution (Xiang et al. 2015; Yang et al. 2015a, b), spatial and temporal variations of chlorophyll- $a$ concentration (Wang et al. 2015a, b, c, d), the impact assessment of Three Gorges Dam's impoundment on river dynamics in the north branch of Yangtze River estuary the ecosystem (Yu et al. 2014) and ecological risk 


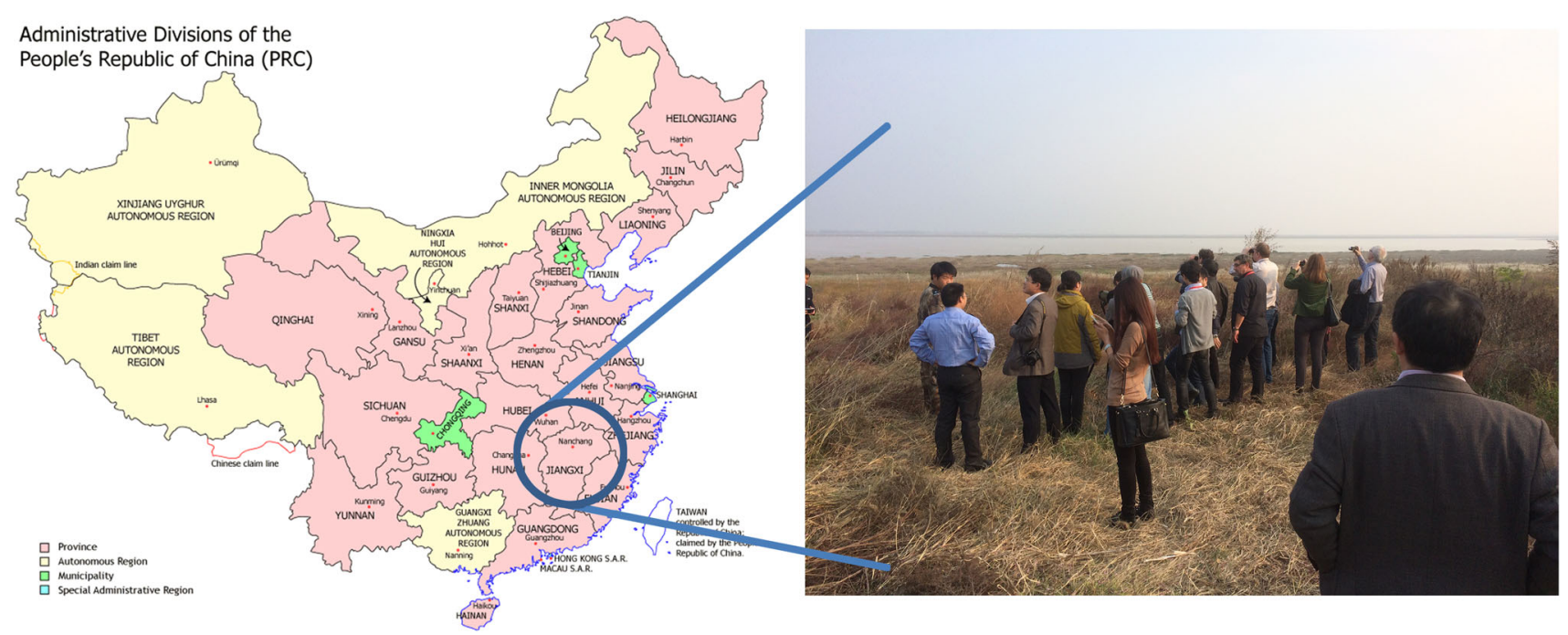

Fig. 1 Poyang Lake, sources: China map (left) https://upload. wikimedia.org/wikipedia/commons/9/99/China_administrative.gif; photography by Olaf Kolditz (right) (see also China Maps statement

assessment of DDTs in typical wetland surface soils of Poyang Lake (He et al. 2013). The Poyang Lake is one of research areas for the Sino-German cooperation since many years (Chen et al. 2015a, b) and the funding of new efforts by the Sino-German Society for Science Promotion is very much acknowledged.

Acknowledgments This Thematic Issue is a melting point of the Sino-German cooperation activities in Environmental Information Science-Information for Knowledge is a very important issue to tackle environmental problems. The Sino-German Centre for Environmental Information Science (RCEIS) is tackling this challenge. Germany has experience in solving environmental problems concerning integrated water resources management (IWRM) inside and outside of Germany. We are very grateful to the Sino-German Centre for Science Promotion [funded by the German Science Foundation (DFG) and the Natural National Science Foundation of China (NSFC)] for supporting the activities by a Cooperation Group funding for 2015-2017. Chinese lakes-here the Poyang Lake-became an important research object worldwide. Within the German research initiative CLIENT (International Partnership for sustainable climate protection as well as environmental technologies and services) funded by German Federal Ministry of Education and Research (BMBF) several projects were started recently to support China in solving the water problems in several lakes areas such as Chaohu (Jiang et al. 2014; Huo et al. 2013, 2014; Wang et al. 2014a, b), Dianchi (Wang et al. 2015c) and Taihu (Xi et al. 2015).

\section{References}

Alam MJ, Yuan D, Jiang YJ et al (2014) Sources and transports of polycyclic aromatic hydrocarbons in the Nanshan underground river, China. Environ Earth Sci 71(4):1967-1976

Al-Khashman OA (2013) Assessment of heavy metals contamination in deposited street dusts in different urbanized areas in the city of Ma'an, Jordan. Environ Earth Sci 70(6):2603-2612 on the journals webpages at http://www.springer.com/earth+sciences+ and+geography/geology/journal/12665)

Beinhorn M, Dietrich P et al (2005) 3-D numerical evaluation of density effects on tracer tests. J Contam Hydrol 81(1-4):89-105

Beyer C, Bauer S et al (2006) Uncertainty assessment of contaminant plume length estimates in heterogeneous aquifers. J Contam Hydrol 87(1-2):73-95

Cao Y, Wang J, Bai Z, Zhou W, Zhao ZQ, Ding X, Li Y (2015) Differentiation and mechanisms on physical properties of reconstructed soils on open-cast mine dump of Loess area. Environ Earth Sci. doi:10.1007/s12665-015-4607-0

Centler F, Shao H, De Biase C et al (2010) GeoSysBRNS-a flexible multidimensional reactive transport model for simulating biogeochemical subsurface processes. Comput Geosci 36(3):397-405

Chen C, Hagemann S, Liu J (2015a) Assessment of impact of climate change on the blue and green water resources in large river basins in China. Environ Earth Sci. doi:10.1007/s12665-014$3782-8$

Chen C, Boernick H, Cai Q et al (2015b) Challenges and opportunities of German-Chinese cooperation in water science and technology. Environ Earth Sci 73(8):4861-4871

Dong G, Yang S, Gao Y et al (2014) Spatial evaluation of phosphorus retention in riparian zones using remote sensing data. Environ Earth Sci 72(5): 1643-1657

Dun Y, Tang C, Shen Y (2014) Identifying interactions between river water and groundwater in the North China Plain using multiple tracers. Environ Earth Sci 72(1):99-110

Dzonzi-Undi J, Li SX (2015) A SWOT analysis of safety and environmental regulation for China and USA: its effect and influence on sustainable development of coal industry. Environ Earth Sci. doi:10.1007/s12665-015-4751-6

Faanu A, Kpeglo DO, Sackey M et al (2013) Natural and artificial radioactivity distribution in soil, rock and water of the Central Ashanti Gold Mine, Ghana. Environ Earth Sci 70(4):1593-1604

Fan Z, Li J, Yue TX, Zhou X, Lan A (2015) Scenarios of land cover in Karst area of southwestern China. Environ Earth Sci. doi:10. 1007/s12665-015-4223-Z

Grathwohl P, Ruegner H, Woehling T et al (2013) Catchments as reactors: a comprehensive approach for water fluxes and solute turnover. Environ Earth Sci 69(2):317-333 
Guo W, Wang C, Zeng X, Ma T, Yang H (2015) Quantifying the spatial variability of rainfall and flow routing on flood response across scales. Environ Earth Sci. doi:10.1007/s12665-015-4456-x

He C, Liu J, Li J et al (2013) Spatial distribution, source analysis, and ecological risk assessment of DDTs in typical wetland surface soils of Poyang Lake. Environ Earth Sci 68(4):1135-1141

Huang LM, Deng CB, Huang N et al (2013) Multivariate statistical approach to identify heavy metal sources in agricultural soil around an abandoned $\mathrm{Pb}-\mathrm{Zn}$ mine in Guangxi Zhuang autonomous region, China. Environ Earth Sci 68(5):1331-1348

Huang SQ, Tian HY, Wu XX, Zhou S, Li XW, Zhang T, Zhao XH, Wang Y, Pei Y, Xu B (2016) Risk analysis of H5N1 highly pathogenic avian influenza in poultry at Poyang Lake area, China. Environ Earth Sci, forthcoming

Huo S, Xi B, Yu X et al (2013) Application of equilibrium partitioning approach to derive sediment quality criteria for heavy metals in a shallow eutrophic lake, Lake Chaohu, China. Environ Earth Sci 69(7):2275-2285

Huo S, Zhang J, Xi B et al (2014) Distribution of nitrogen forms in surface sediments of lakes from different regions, China. Environ Earth Sci 71(5):2167-2175

Jähnig SC, Shah DN, Shah RDT, Li FQ, Cai QH, Sundermann A, Tonkin JD, Stendera S (2015) Community-environment relationships of riverine invertebrate communities in central Chinese streams. Environ Earth Sci. doi:10.1007/s12665-015-4466-8

Jiang T, Huo S, Xi B et al (2014) The influences of land-use changes on the absorbed nitrogen and phosphorus loadings in the drainage basin of Lake Chaohu, China. Environ Earth Sci 71(9):4165-4176

Kalbacher T, Delfs JO, Shao H et al (2012) The IWAS-ToolBox: software coupling for an integrated water resources management. Environ Earth Sci 65(5):1367-1380

Kalbus E, Kalbacher $\mathrm{T}$ et al (2012) Integrated water resources management under different hydrological, climatic and socioeconomic conditions. Environ Earth Sci 65(5):1363-1366

Li P, Qian H, Wu J et al (2014a) Occurrence and hydrogeochemistry of fluoride in alluvial aquifer of Weihe River, China. Environ Earth Sci 71(7):3133-3145

Li Q, Zhou J, Chen B et al (2014b) Toxic metal contamination and distribution in soils and plants of a typical metallurgical industrial area in southwest of China. Environ Earth Sci 72(6):2101-2109

Li X, Chen Z, Chen Z (2014c) Distribution and fractionation of rare earth elements in soil-water system and human blood and hair from a mining area in southwest Fujian Province, China. Environ Earth Sci 72(9):3599-3608

Li X, Feng L, Huang C et al (2014d) Potential hazardous elements (PHEs) in atmospheric particulate matter (APM) in the south of Xi'an during the dust episodes of 2001-2012 (NW China): chemical fractionation, ecological and health risk assessment. Environ Earth Sci 71(9):4115-4126

Maxwell RM, Putti M, Meyerhoff S et al (2014) Surface-subsurface model intercomparison: a first set of benchmark results to diagnose integrated hydrology and feedbacks. Water Resour Res 50(2):1531-1549

Mitchell HB (2012) Data fusion: concepts and ideas. Springer, Berlin

Nichols NK (2010) Mathematical concepts of data assimilation. In: Lahoz W, Khattatov B, Menard R (eds) Data assimilation: making sense of observations. Springer, Berlin, pp 13-39

Qu B, Sillanpää M, Zhang Y, Guo JM, Abdel Wahed MSM, Kang S (2015) Water chemistry of the headwaters of the Yangtze River. Environ Earth Sci. doi:10.1007/s12665-015-4174-4

Rink K, Kalbacher T et al (2012) Visual data exploration for hydrological analysis. Environ Earth Sci 65(5):1395-1403

Seegert J, Berendonk TU, Bernhofer C et al (2014) Integrated water resources management under different hydrological, climatic and socio-economic conditions: results and lessons learned from a transdisciplinary IWRM project IWAS. Environ Earth Sci 72(12):4677-4687

Serbula SM, Kalinovic TS, Kalinovic JV et al (2013) Exceedance of air quality standards resulting from pyro-metallurgical production of copper: a case study, Bor (Eastern Serbia). Environ Earth Sci 68(7):1989-1998

Song Y, Liu R, Sun YY et al (2015) Waste water treatment and pollution control in the Liao River Basin. Environ Earth Sci 73(9):4875-4880. doi:10.1007/s12665-015-4333-7

Steefel CI, Appelo CAJ, Arora B et al (2015) Reactive transport codes for subsurface environmental simulation. Comput Geosci 19(3):445-478

Su X, Wang H, Zhang Y et al (2014) The present situation and evaluation of nitrate pollution in soil in a regional aeration zone: using the proluvial fan agriculture irrigation district of Hunhe River in northeast China as an example. Environ Earth Sci 71(4):1881-1891

Tay CK, Biney CA (2013) Levels and sources of polycyclic aromatic hydrocarbons (PAHs) in selected irrigated urban agricultural soils in Accra, Ghana. Environ Earth Sci 68(6):1773-1782

Wang C, Ji J, Yang Z et al (2013a) The contamination and transfer of potentially toxic elements and their relations with iron, vanadium and titanium in the soil-rice system from Suzhou region, China. Environ Earth Sci 68(1):13-21

Wang X, Ding W, Nan Z et al (2013b) Fraction of Cd in oasis soil and its bioavailability to commonly grown crops in Northwest China. Environ Earth Sci 70(1):471-479

Wang Z, Pang Z, Guo Q et al (2013c) Introducing a land-use-based spatial analysis method for human health risk evaluation of soil heavy metals. Environ Earth Sci 70(7):3225-3235

Wang L, Lu X, Ren C et al (2014a) Contamination assessment and health risk of heavy metals in dust from Changqing industrial park of Baoji, NW China. Environ Earth Sci 71(5):2095-2104

Wang X, Xi B, Huo S et al (2014b) Polychlorinated biphenyls residues in surface sediments of the eutrophic Chaohu Lake (China): characteristics, risk, and correlation with trophic status. Environ Earth Sci 71(2):849-861

Wang CL, Zhao N, Yue TX, Zhao MW, Chen C (2015a) Change trend of monthly precipitation in China with an improved surface modeling method. Environ Earth Sci. doi:10.1007/s12665-0144012-0

Wang J, Zhang Y, Yang F et al (2015b) Spatial and temporal variations of chlorophyll-a concentration from 2009 to 2012 in Poyang Lake, China. Environ Earth Sci 73(8):4063-4075

Wang SR, Zheng BH, Chen C, Dohmann M, Kolditz O (2015c) Water of the Erhai and Dianchi lakes. Environ Earth Sci 74(5):3685-3688. doi:10.1007/s12665-015-4727-6

Wang YF, Yue TX, Du ZP, Zhao MW (2015d) Improving the accuracy of the height-diameter equation using the classified factors method. Environ Earth Sci. doi:10.1007/s12665-015-4168-2

Xi BD, Su J, Sun YY, Huo SL, Zheng BH, Tiehm A, Kolditz O (2015) Water of the Taihu Lake. Environ Earth Sci 74(5):3929-3933. doi:10.1007/s12665-015-4732-9

Xiang S, Nie F, Wu D et al (2015) Nitrogen distribution and diffusive fluxes in sediment interstitial water of Poyang Lake. Environ Earth Sci 74(3):2609-2615

Xiao S, Xiao H, Peng X et al (2014) Daily and seasonal stem radial activity of Populus euphratica and its association with hydroclimatic factors in the lower reaches of China's Heihe River basin. Environ Earth Sci 72(2):609-621

Xie H, Jiang W, Wang Y et al (2015a) Thermodynamics study on the generation of electricity via $\mathrm{CO}_{2}$-mineralization cell. Environ Earth Sci. doi:10.1007/s12665-015-4731-x

Xie YY, Chi YP, Meng J, Guo LF, Wang YR (2015b) Grain-size and $\mathrm{Sr}-\mathrm{Nd}$ isotopic compositions of dry- and wet-deposited dust 
during the same dust-storm event in Harbin, China: implications for source, transport-deposition modes, dynamic mechanism and formation of eolian loess. Environ Earth Sci. doi:10.1007/ s12665-015-4747-2

$\mathrm{Xu} \mathrm{B}$, Gong P (2008) Noise estimation in a noise-adjusted principal component transformation and hyperspectral image restoration. Can J Remote Sens 34:271-286

Xu G, Lu K, Li ZB, Li P, Wang T, Yang YY (2015) Impact of soil and water conservation on soil organic carbon content in a catchment of the middle Han River, China. Environ Earth Sci. doi:10.1007/s12665-015-4749-0

Yan CQ, Zhao G, Yue TX, Chen C, Liu J, Li H, Su N (2015) Speeding-up the high accuracy surface modelling method with GPU. Environ Earth Sci. doi:10.1007/s12665-015-4138-8

Yang CL, Guo RP, Yue QL et al (2013) Environmental quality assessment and spatial pattern of potentially toxic elements in soils of Guangdong Province, China. Environ Earth Sci 70(4):1903-1910

Yang H, Wang C, Ma T, Guo W (2015a) Accuracy assessment of interpolation methods in grid DEMs based on a variance-scale relation. Environ Earth Sci. doi:10.1007/s12665-015-4388-5

Yang Z, Wang L, Liang $\mathrm{T}$ et al (2015b) Nitrogen distribution and ammonia release from the overlying water and sediments of Poyang Lake, China. Environ Earth Sci 74(1):771-778

Yin $\mathrm{H}, \mathrm{Mu}$ S, Zhao L et al (2013) Microscopic morphology and elemental composition of size distributed atmospheric particulate matter in Urumqi, China. Environ Earth Sci 69(7): 2139-2150

Yin AJ, Zhang M, Gao C, Yang XH, Xu Y, Wu PB, Zhang H (2015) Salinity evolution of coastal soils following reclamation and intensive usage, Eastern China. Environ Earth Sci. doi:10.1007/ s12665-015-4752-5

Yu S, Yang J, Liu G (2014) Impact assessment of Three Gorges Dam's impoundment on river dynamics in the north branch of Yangtze River estuary, China. Environ Earth Sci 72(2):499-509

Yue TX, Zhang LL, Zhao N, Zhao MW, Chen CF, Du ZP, Song DJ, Fan ZM, Shi WJ, Wang SH, Yan CQ, Li QQ, Sun XF, Yang H, Wilson J, Xu B (2015) A review of recent developments in HASM. Environ Earth Sci. doi:10.1007/s12665-015-4489-1

Zhang H (2013) Arsenic movement and traces in the groundwater from the Hetao area, Inner Mongolia. Environ Earth Sci 69(5):1579-1588

Zhao MW, Yue TX, Zhao N, Yang X, Wang Y, Zhang XY (2015a) Parallel algorithm of a modified surface modeling method and its application in digital elevation model construction. Environ Earth Sci. doi:10.1007/s12665-015-4177-1

Zhao N, Chen CF, Zhou X, Yue TX (2015b) A comparison of two downscaling methods for precipitation in China. Environ Earth Sci. doi:10.1007/s12665-015-4750-7

Zhao S, Wang L, Cheng W, Liu H, He W (2015c) Rectification methods comparison for the ASTER GDEM V2 data using the ICEsat/GLA14 data in the Lvliang Mountains, China. Environ Earth Sci. doi:10.1007/s12665-015-4614-1

Zhou Y, Wang Y, Li Y et al (2013) Hydrogeochemical characteristics of central Jianghan Plain, China. Environ Earth Sci 68(3):765-778

Zhou Y, Khu ST, Xi B et al (2014) Status and challenges of water pollution problems in China: learning from the European experience. Environ Earth Sci 72(4):1243-1254 